\title{
Landfill Site Selection Using GIS and Multi-Criteria Decision-Making AHP and SAW Methods: A Case Study in Sulaimaniyah Governorate, Iraq
}

\author{
Karwan Alkaradaghi1 ${ }^{1,2,3}$, Salahalddin S. Ali ${ }^{2,4,5}$, Nadhir Al-Ansari ${ }^{*}$, Jan Laue ${ }^{1}$ \\ ${ }^{1}$ Lulea University of Technology, Lulea, Sweden \\ ${ }^{2}$ Department of Geology, College of Science, Sulaimani University, Sulaimaniyah, Iraq \\ ${ }^{3}$ Kurdistan Institution for Strategic Studies and Scientific Research, Sulaimaniyah, Iraq \\ ${ }^{4}$ Komar University of Science and Technology, Sulaimaniyah, Iraq \\ ${ }^{5}$ Komar Research Center, Sulaimaniyah, Iraq \\ Email: nadhir.alansari@ltu.se, ^salah.saeed@komar.edu.iq
}

How to cite this paper: Alkaradaghi, K., Ali, S.S., Al-Ansari, N. and Laue, J. (2020) Landfill Site Selection Using GIS and Multi-Criteria Decision-Making AHP and SAW Methods: A Case Study in Sulaimaniyah Governorate, Iraq. Engineering, 12, 254-268. https://doi.org/10.4236/eng.2020.124021

Received: March 17, 2020

Accepted: April 20, 2020

Published: April 23, 2020

Copyright ( $) 2020$ by author(s) and Scientific Research Publishing Inc. This work is licensed under the Creative Commons Attribution International License (CC BY 4.0).

http://creativecommons.org/licenses/by/4.0/

\begin{abstract}
Lack of land for waste disposal is one of the main problems facing urban areas in developing countries. The Sulaimaniyah Governorate, located in northern Iraq, is one of the main cities of the country in the Kurdistan Region, covering an area of $2400 \mathrm{~km}^{2}$. Currently, there is no landfill site in the study region that meets scientific and environmental requirements, inappropriate dumping of solid waste causes adverse effects on the environment, economic and urban aesthetic. To overcome with this phenomenon, it is very crucial to suggest a landfill site, even in countries that recycle or burn their waste to protect the environment. Landfill sites should be carefully selected by considering all regulations and other restrictions. The integration of geographic information systems and multi-criteria decision analysis is used in this study to select suitable landfill locations in the region, for this purpose, thirteen layers are prepared according to their importance including urban area, villages, rivers, groundwater depth, slope, elevation, soil types, geological formations, roads, oil and gas field, land use classification, archaeological site and power lines. Two different methods (simple additive weighting and analytic hierarchy process) are implemented in a geographical information system to obtain the suitability index map for candidate landfill sites, where all these sites satisfied the scientific and environmental criteria which were adopted in this study. The comparison of the maps resulting from these two different methods demonstrates that both methods produced consistent results.
\end{abstract}




\section{Keywords}

Landfill Site, Criteria Weights, GIS Software, Analytic Hierarchy Process (AHP), Simple Additive Weighting (SAW) Method

\section{Introduction}

Solid waste management is considered to be a significant issue in developing countries. Population growth, economic recovery and industrial growth are all reasons to increase the generation of solid waste in developing countries [1].

Despite the use of many efficient processes such as reuse and recycling, appropriate landfill disposal is still the most prevalent method of minimizing adverse effects on the environment and waste management [2]. The common issue facing all developing countries is the disposal of solid waste and the availability of land, considering its significant adverse impacts on the environment [3] [4].

Currently, there is no landfill site in the study area that fulfils scientific and environmental requirements to resolve the waste dump site issue, the process of selecting a landfill site is considered complicated task, the combination of multi-criteria decision-making (MCDM) approaches and the Geographic Information System (GIS) generates a powerful spatial decision support that provides the opportunity to effectively create land suitability maps for waste disposal sites [5], multi-criteria decision-making (MCDM) and GIS have been used commonly in different fields and implementations, including the integrated eco-environment Assessment of Soil [6], land evaluation for peri-urban agriculture [7], possibility of groundwater pollution [8]. GIS becomes an important tool for smart decisions on landfill site selection [9].

In order to achieve the research objective, thirteen important criteria that have influenced the environment and waste management have been considered as a data set for the decision model, two techniques of multi-criteria decision-making (MCDM) have been used in this research, which are analytic hierarchy process (AHP) and simple additive weighting (SAW) methods to assess the weights of prospective variables for selecting landfill sites [10] [11] [12]. Geographic Information System (GIS) with AHP and SAW methods are the most common techniques in MCDM with a high capacity to manage complicated problems with large data during the decision-making process [13] [14] [15].

This study aimed to compare both methods and establish an appraisal blueprint to find the best candidate landfill sites that realize the environmental and scientific criteria.

\section{Study Area}

Sulaimaniyah is among the major cities in the Kurdistan region. The city is situated northwest of Iraq between latitude $35^{\circ} 45^{\prime} 0^{\prime \prime} \mathrm{N}, 36^{\circ} 0^{\prime} 0^{\prime \prime} \mathrm{N}$ and longitude $44^{\circ} 45^{\prime} 0^{\prime \prime} \mathrm{E}, 45^{\circ} 45^{\prime} 0^{\prime \prime} \mathrm{E}$ approximately $370 \mathrm{~km}$ north east of Baghdad, Iraq's capital. 
The city is bounded in the north-east and south-west by the Mountains and is situated in a low-lying land covering an area of approximately $2400 \mathrm{~km}^{2}$. The study area is characterized by a separate Mediterranean-type continental interior climate with average annual precipitation ranging from (500 to $700 \mathrm{~mm}$ ). The Sulaimaniyah governorate had a population of approximately 856,990 in 2017 [16]. Figure 1 shows the administrative boundary unit of the Sulaimaniyah governorate [17]. All types of waste dumped without treatment in an open area overlooking the Tanjaro River.

\section{Materials and Methods}

\subsection{Dataset Criteria Map}

In order to proceed suitable landfill site map, thirteen criteria as layer maps were prepared using GIS spatial analysis tools over the study area, these layers were urban area, villages, rivers, groundwater depth, slope, elevation, soil types, geological formations, roads, oil and gas field, land use classification, archaeological site and power lines, in accordance with environmental standards, natural and artificial factors for landfill site selection.

The source of the data obtained from official government authorities and International organization data base, official government authorities data includes
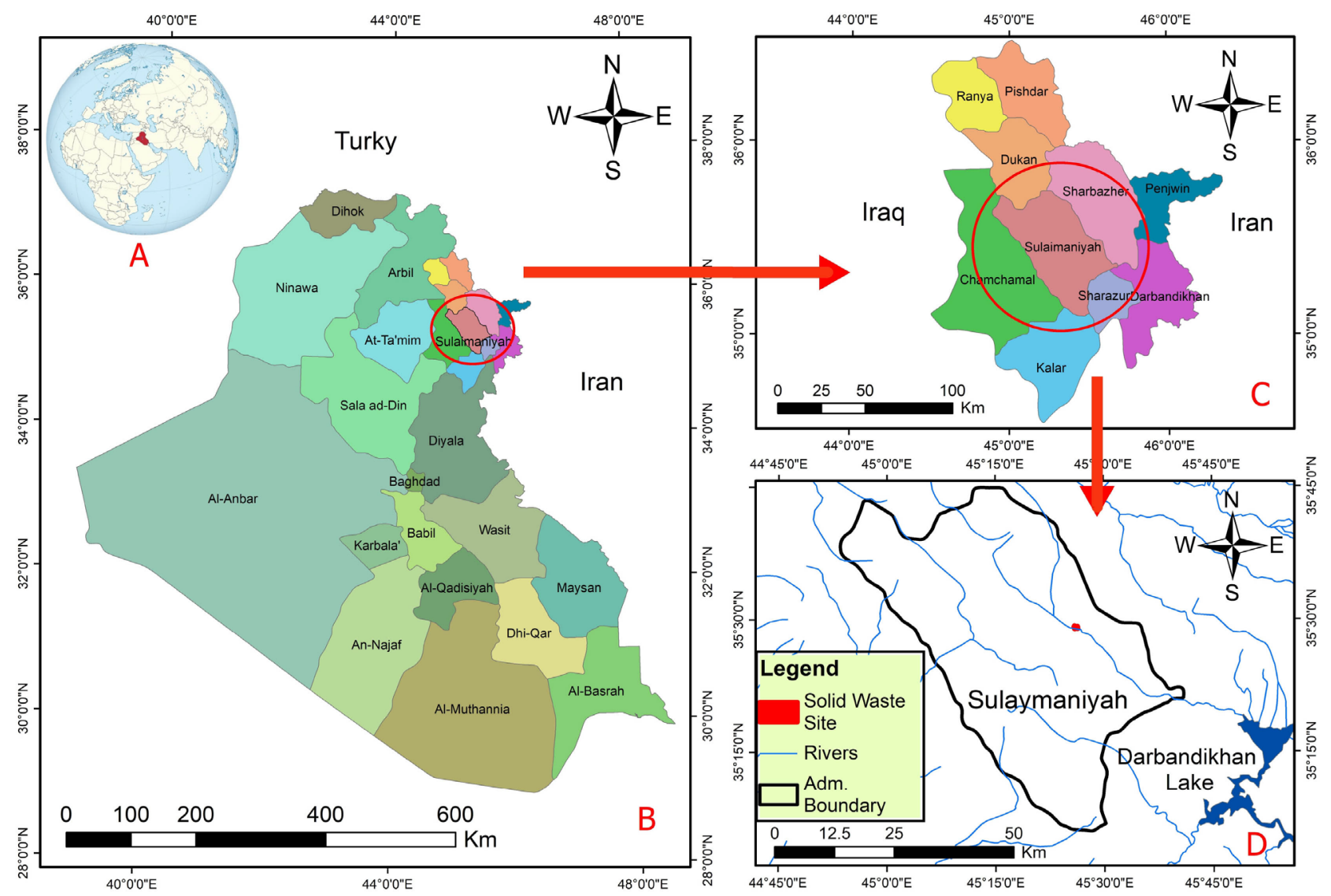

Figure 1. Location map of the study area. 
urban area, archaeological sites, power lines, oil and gas fields, villages, soil and geological formations. The river, road, and elevation data downloaded from the United States Geological Survey USGS Earth Explorer, Spatial analysis tools used in GIS to convert the slope map from a digital elevation model.

Water level depth data were obtained from the Sulaymaniyah groundwater authority and GIS was applied to water level using the "Kriging" method in special analysis tools to create a groundwater table map of the study area. The land use classification was prepared using satellite data and processed by remote sensing software (ENVI 5.4).

\subsection{Criteria Restriction}

Determining the allowable distance from landfill sites requires consideration of government regulations, prospective environmental risks, public health and economical evaluation for each criterion [18] [19].

Specific geographical features established using buffer zones by spatial analysis of GIS software around each criterion, buffer zones were created based on previous literature studies to determine the distance from each feature to the specified criteria. A buffer zone is an area that can be divided by grade to reduce or eliminate the impact of land use activities on vulnerable regions or natural features, restricted criteria and suggested buffer values for the study area as shown in Table 1.

\subsection{Sub-Criteria Rating Values}

Each criterion was classified into sub-criteria and assigned a suitability rating

Table 1. Restricted criteria and suggested buffer values for the study area.

\begin{tabular}{cccc}
\hline No. & Criteria & Restricted Criteria (Buffer Zone) & Reference Suggestion \\
\hline 1. & Rivers & $1 \mathrm{~km}$ & {$[20][21][22]$} \\
2. & Roads & $500 \mathrm{~m}$ & {$[5][14][23]$} \\
3. & Elevation & $1350-2100 \mathrm{~m}$ Restricted & {$[24][25][26][27]$} \\
4. & Urban area & $5 \mathrm{~km}$ & {$[5][9][14][24]$} \\
5. & Soil types & high permeable soil restricted & {$[20][28]$} \\
6. & Slope & Restricted areas $15-50$ degree & {$[2][24][26]$} \\
7. & Powerline & $30 \mathrm{~m}$ & {$[9][29]$} \\
8. & Archaeological sites & $1 \mathrm{~km}$ & {$[30][31][32]$} \\
9. & Oil and Gas Field & $5 \mathrm{~km}$ & {$[11][12]$} \\
10. & Villages & $1 \mathrm{~km}$ & {$[33]$} \\
11. & Geological formations & Restricted faults & {$[6][34][35]$} \\
12. & Land use & Agriculture, water body, build up, & {$[20]$} \\
13. & Depth to groundwater level & Water depth $19-35 \mathrm{~m}$ Restricted & {$[24][26]$} \\
\hline
\end{tabular}


value from zero to ten [36] [37]. The criteria rating and importance of its priority were specified based on restrictions on category priorities for the field of study and on the basis of literature and research experts in the field of selecting solid waste sites.

The ranking value for each criterion and sub-criteria was determined following several steps, including in a series (Buffer, Clip, Extract, Overlay, Proximity, Convert, Reclassify and Map Algebra) using GIS spatial analysis tools. Sub-criteria buffer zone and rating values for the input layer are shown in Table 2.

Table 2. Layers buffer zone with sub-criteria ratings.

\begin{tabular}{|c|c|c|c|}
\hline No. & Criteria & Sub-Criteria and Buffer Zone & Rating Values \\
\hline \multirow{2}{*}{1} & \multirow{2}{*}{ Rivers (km) } & $0-1$ & 0 \\
\hline & & $>1$ & 10 \\
\hline \multirow{5}{*}{2} & \multirow{5}{*}{ Roads $(\mathrm{km})$} & $0-0.5$ & 0 \\
\hline & & $0.5-1$ & 7 \\
\hline & & $1-2$ & 10 \\
\hline & & $2-3$ & 5 \\
\hline & & $>3$ & 3 \\
\hline \multirow{5}{*}{3} & \multirow{5}{*}{ Elevation (a.m.s.l) } & $1350-2100$ & 2 \\
\hline & & $1100-1350$ & 4 \\
\hline & & $920-1100$ & 6 \\
\hline & & $500-750$ & 8 \\
\hline & & $750-920$ & 10 \\
\hline \multirow{5}{*}{4} & \multirow{5}{*}{ Urban area $(\mathrm{km})$} & $0-5$ & 0 \\
\hline & & $5-10$ & 3 \\
\hline & & $10-15$ & 5 \\
\hline & & $15-20$ & 7 \\
\hline & & $>20$ & 10 \\
\hline \multirow{4}{*}{5} & \multirow{4}{*}{ Soil types } & S33 & 4 \\
\hline & & S37 & 6 \\
\hline & & S38 & 8 \\
\hline & & S39 & 10 \\
\hline \multirow{4}{*}{6} & \multirow{4}{*}{ Slope (degree) } & $15-50$ & 4 \\
\hline & & $10-15$ & 6 \\
\hline & & $5-10$ & 8 \\
\hline & & $0-5$ & 10 \\
\hline \multirow{2}{*}{7} & \multirow{2}{*}{ Power lines (m) } & $0-30$ & 0 \\
\hline & & $>30$ & 10 \\
\hline \multirow{3}{*}{8} & \multirow{3}{*}{ Archaeological site $(\mathrm{km})$} & $0-1$ & 0 \\
\hline & & $1-3$ & 5 \\
\hline & & $>3$ & 10 \\
\hline
\end{tabular}




\begin{tabular}{|c|c|c|c|}
\hline \multicolumn{4}{|c|}{ Continued } \\
\hline \multirow[b]{2}{*}{9} & \multirow[b]{2}{*}{ Oil and Gas Field (km) } & $0-5$ & 0 \\
\hline & & $>5$ & 10 \\
\hline \multirow{3}{*}{10} & \multirow{2}{*}{ Villages (km) } & $0-1$ & 0 \\
\hline & & $>1$ & 10 \\
\hline & \multirow{7}{*}{ Geological Formations } & Fault G1 & 0 \\
\hline \multirow{6}{*}{11} & & $\mathrm{D} 1$ & 2 \\
\hline & & E2 & 3 \\
\hline & & $\mathrm{F} 1$ & 4 \\
\hline & & $\mathrm{C} 4$ & 6 \\
\hline & & B4 & 8 \\
\hline & & A3 & 10 \\
\hline \multirow{10}{*}{12} & \multirow{10}{*}{ Land Use } & Airport & 0 \\
\hline & & Build up & 0 \\
\hline & & Water body & 0 \\
\hline & & Factories \& Industrial area & 0 \\
\hline & & Agriculture \& fertile land & 0 \\
\hline & & Non-fertile agriculture land & 0 \\
\hline & & Forest & 5 \\
\hline & & Pasture & 8 \\
\hline & & Rock & 10 \\
\hline & & Unused Land & 10 \\
\hline \multirow{5}{*}{13} & & $19-35$ & 2 \\
\hline & & $35-50$ & 4 \\
\hline & Depth to groundwater level (m) & $50-65$ & 6 \\
\hline & & $65-80$ & 8 \\
\hline & & $80-280$ & 10 \\
\hline
\end{tabular}

(a.m.s.l.): Above Mean Sea Level.

In this revise, sub criteria rating value of 0 is corresponding to the nearest restricted area from the landfill, and a rating value of 10 was provided best area, for example the sub-criteria "Geological Formations" consisted of seven groups G1, D1, E2, F1, C4, B4 and A3 respectively (Figure 3(H)) were given. ratings of $0,2,3,4,6,8$ and 10 respectively, The suitability index for these groups was graded according to the lithology and permeability of the sediments due to the distribution of grain size [38]. Buffer zones and suitability index maps as shown in Figures 2-4.

\subsection{Multi-Criteria Decision-Making Methods}

Pairwise comparison implemented in the matrix for all criteria through the 
priority of the importance intensity of one activity over another using a numerical scale of 9 points [39].
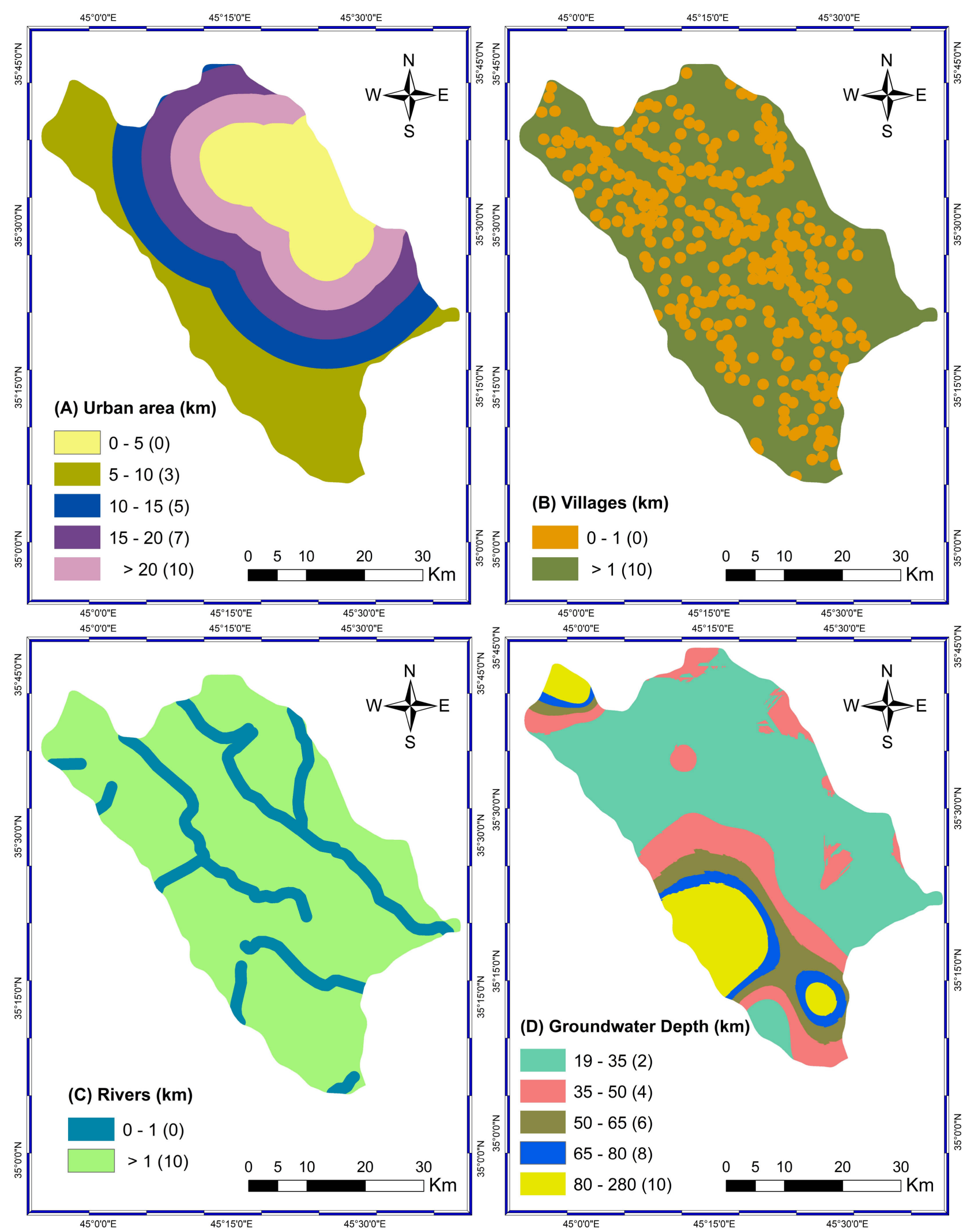

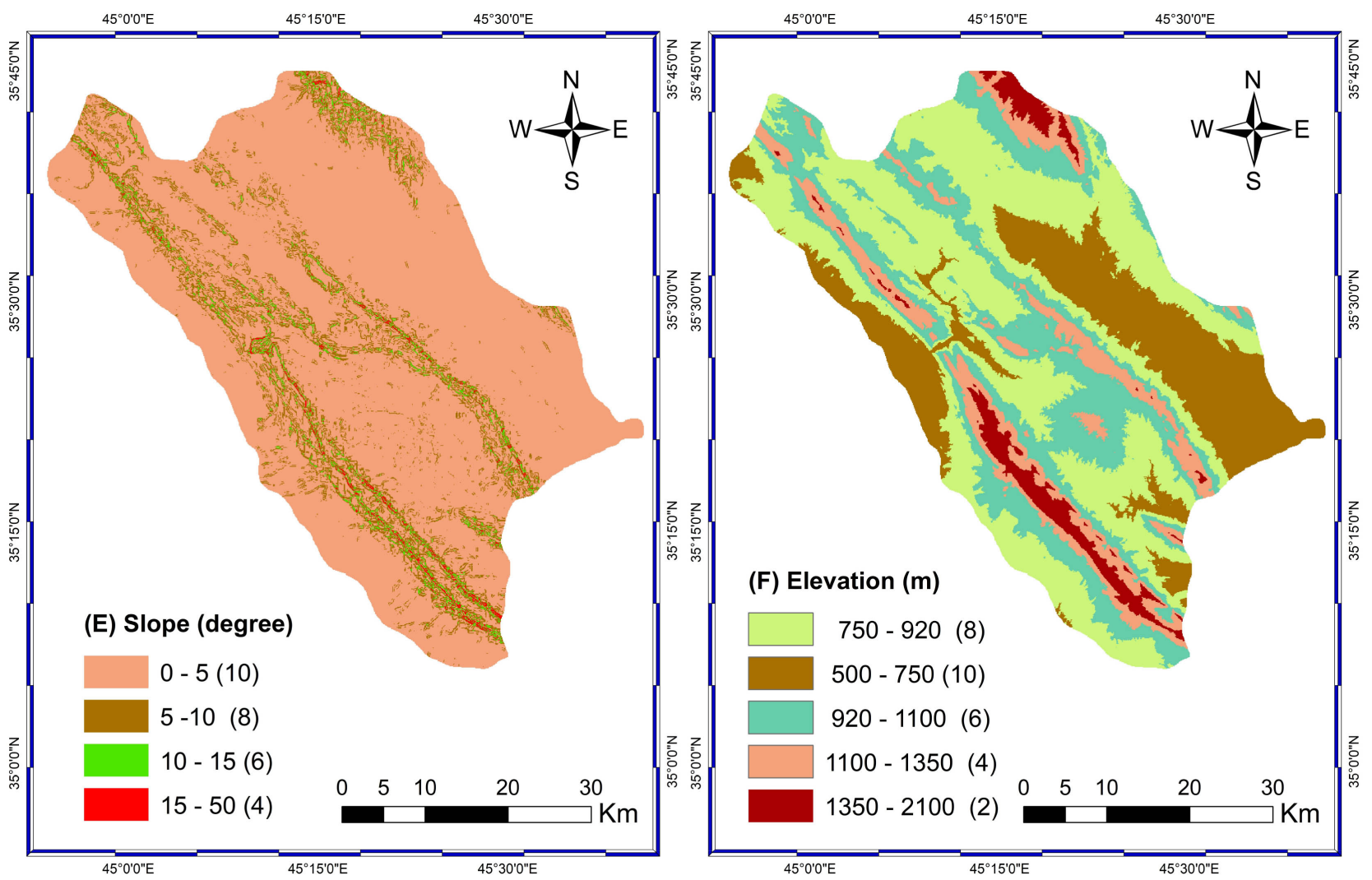

Figure 2. Buffer zones and suitability index maps: (A) Urban area; (B) Villages; (C) Rivers; (D) Groundwater depth; (E) Slope; (F) Elevation.
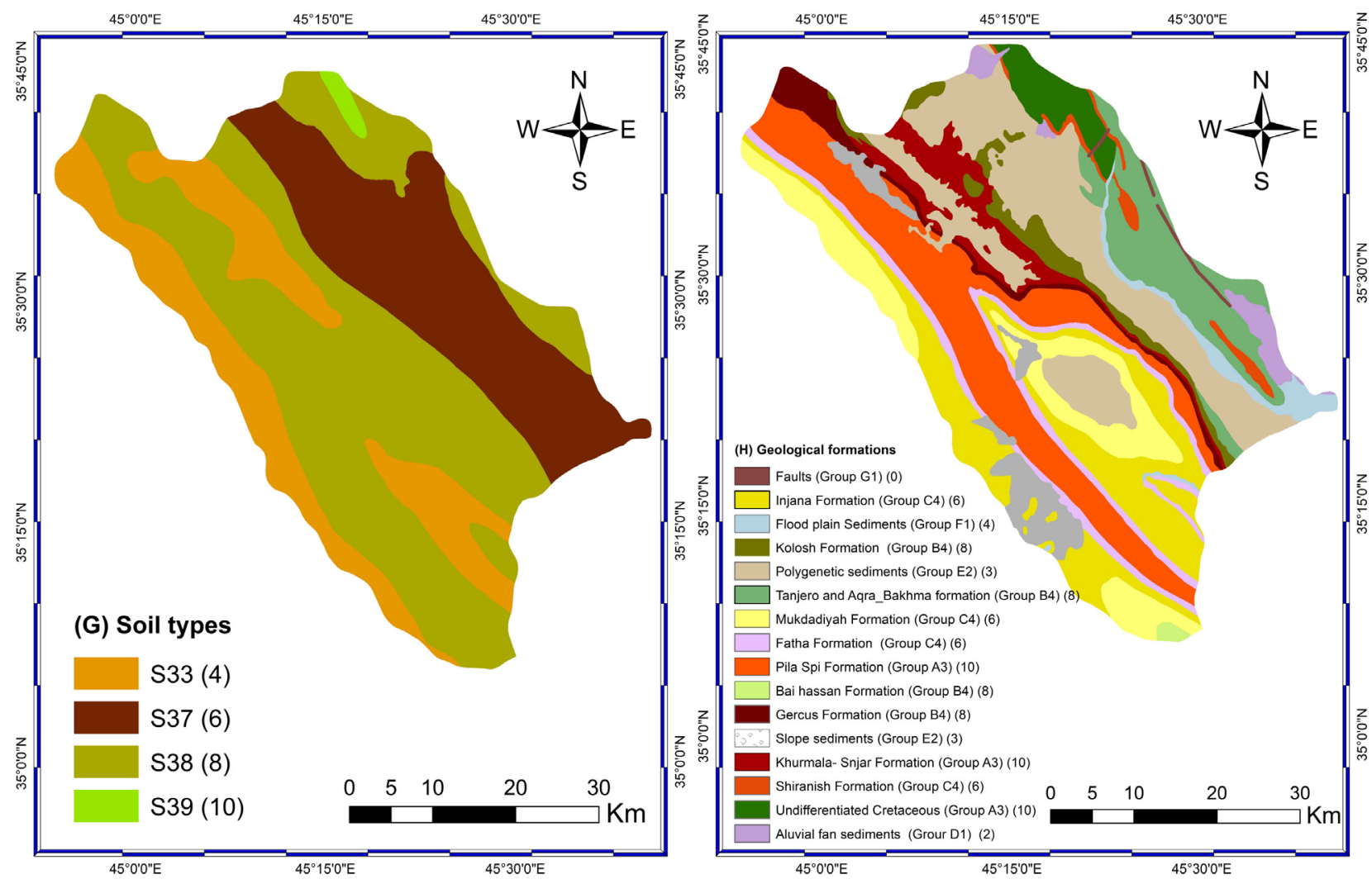

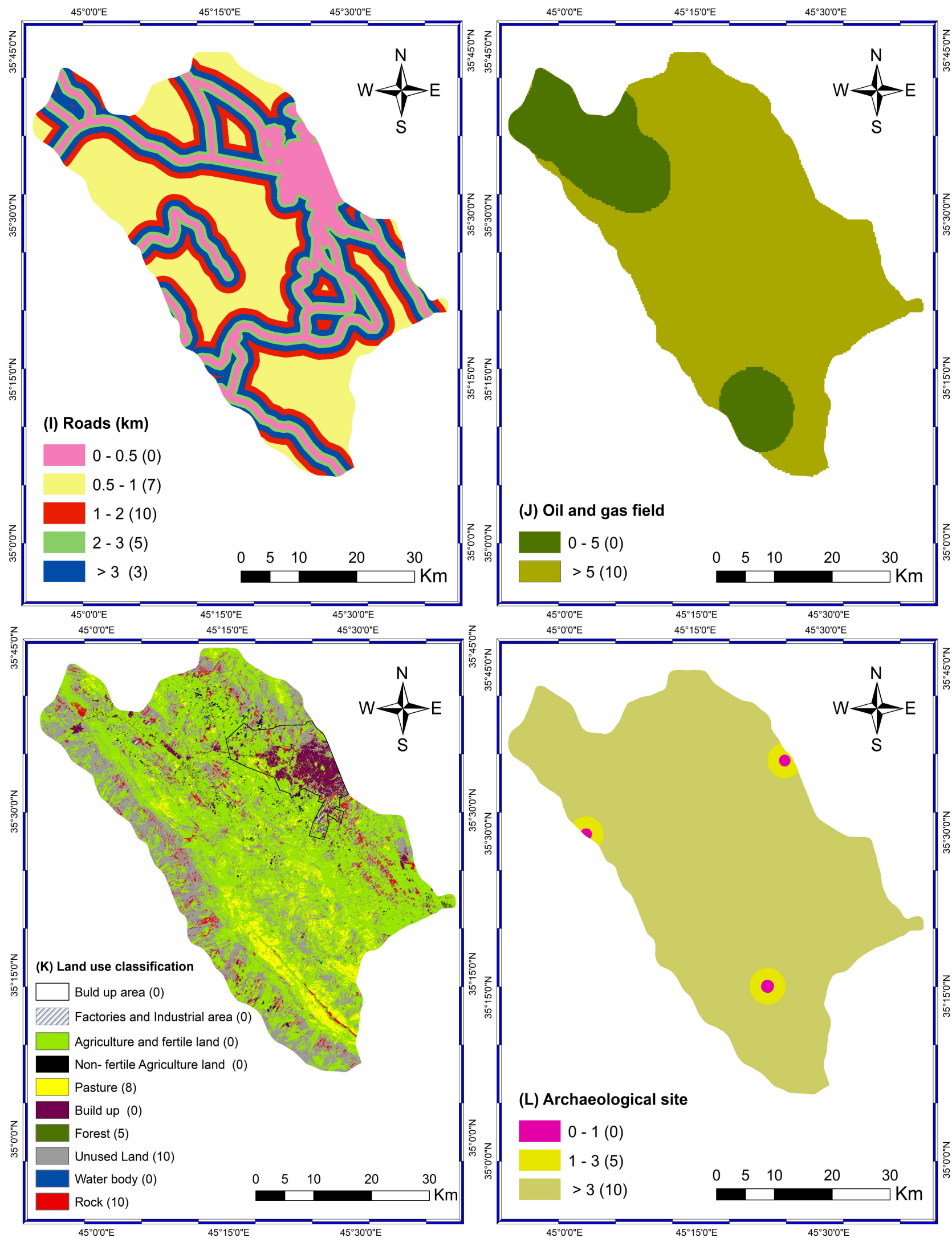

Figure 3. Buffer zones and suitability index maps: (G) Soil types; (H) Geological formations; (I) Roads; (J) Oil and gas field; (K) Land use classification; (L) Archaeological site. 


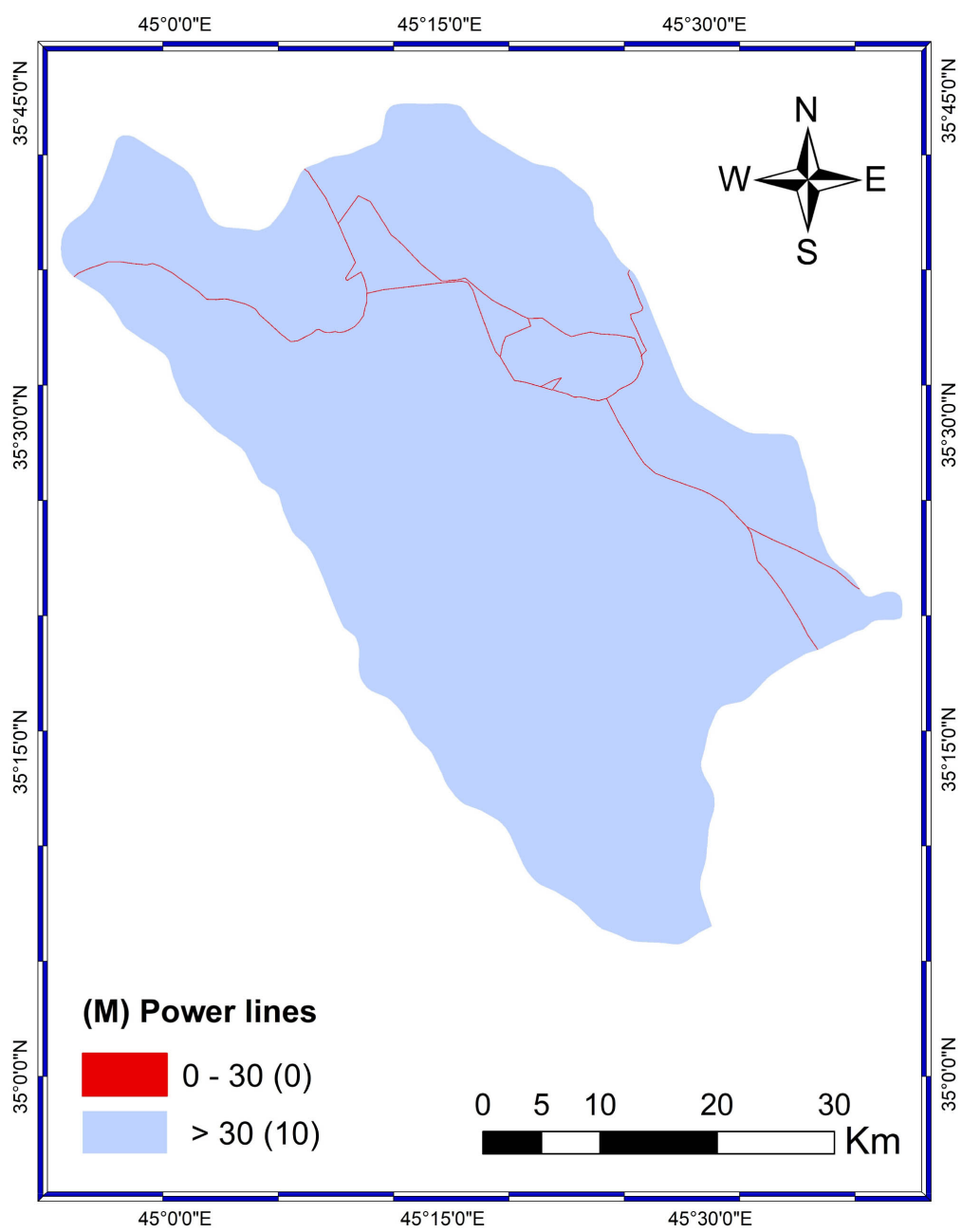

Figure 4. Buffer zone and suitability index map: (A) Power lines.

The upper triangular matrix is filled with the comparative criteria values and the lower triangular matrix is completed with the upper reciprocal values [10] [11]. The eigenvalue is calculated by multiplying the value for each criterion in each column in the same row in the matrix of the pairwise comparison. The priority vector $\left(P r_{i}\right)$ is determined by normalizing the eigenvalue to 1 [39] as follows:

$$
\operatorname{Pr}_{i}=\frac{E g_{i}}{\left(\sum_{i=1}^{n} E g_{i}\right)}
$$

where, $E g_{i}=$ eigenvalue for the row $(i)\left(E g_{i}=\left(a_{11} \times a_{12} \times a_{13} \cdots \times a_{1 n}\right)^{1 / n}\right) ; n=$ number of elements in matrix row (i).

The consistency index calculated according to [39].

The maximum lambda $\left(\lambda_{\max }\right)$ is obtained from the summation of products between each element of priority vector and the sum of columns of the reciprocal matrix as shown in the following formula:

$$
\lambda_{\max }=\sum_{j=1}^{n}\left[W_{j} \sum_{i=1}^{m} a_{i j}\right]
$$


where, $W_{j}$ is the value of weight for each criterion which corresponds to the priority vector in the decision matrix and $a_{i j}$ is the criteria in each column in the matrix.

$$
\mathrm{CI}=\left(\lambda_{\max }-n\right) /(n-1)
$$

where, CI consistency index and $\mathrm{n}$ is size or order of the matrix, $\left(\lambda_{\max }\right)$ which is equivalent to the priority vector in the matrix of decision [39].

The consistency ratio (CR) depends on the size of the matrix $(n=13)$ thus, random index value $(\mathrm{RI}=1.56)$ [39]. Table 3 shows the Random inconsistency value RI in different sizes for a matrix [24] [40].

$$
\mathrm{CI}=\mathrm{CI} / \mathrm{RI}
$$

Simple additive weighting (SAW) is a ranking method and defined as a weighted linear combination or scoring method [39].

$$
W_{i}=\frac{A_{i}}{\sum_{j=1}^{n} A_{j}} j=1,2, \cdots, n
$$

where, $W_{i}$ is the normalized weight of each criterion which was, $A_{i}$ is the weight of each criterion of area $(i)$ under criterion $(j) ; \mathrm{n}$ is criteria number.

\section{Results and Discussion}

The matrix of pairwise comparisons with SAW and AHP weighs as presented in Table 4. The maximum lambda $\left(\lambda_{\max }\right)=13.51, \mathrm{CI}=0.04$ and $\mathrm{CR}=0.027$, If $\mathrm{CR}$ is less than 0.1 the ratio indicates a reasonable consistency level in the pairwise comparison [41]. The final map shows the suitability index for landfill sites in Sulaimaniyah Governorate which was divided into four categories of suitable areas, including: unsuitable, moderately suitable, suitable and most suitable areas [12], suitability index with areas for all categories of the SAW and AHP methods as shown in Figure 5.

Table 3. Random inconsistency indices for different values of (n) [24] [40].

\begin{tabular}{cccccccccccccc}
\hline $\boldsymbol{n}$ & 1 & 2 & 3 & 4 & 5 & 6 & 7 & 8 & 9 & 10 & 11 & 12 & 13 \\
\hline $\mathrm{RI}$ & 0 & 0 & 0.58 & 0.9 & 1.12 & 1.24 & 1.32 & 1.41 & 1.45 & 1.49 & 1.51 & 1.48 & 1.56 \\
\hline
\end{tabular}

Table 4. Pairwise comparison matrix with (AHP) and (SAW) methods.

\begin{tabular}{ccccccccccccccccc}
\hline & A & B & C & D & E & F & G & H & I & J & K & L & M & NW & AHP & SAW \\
\hline A & 1 & 2 & 2 & 3 & 4 & 4 & 5 & 5 & 6 & 6 & 7 & 8 & 9 & 0.211 & 0.219 & 0.124 \\
B & 0.5 & 1 & 1 & 2 & 3 & 3 & 4 & 4 & 5 & 5 & 6 & 7 & 8 & 0.149 & 0.158 & 0.111 \\
C & 0.5 & 1 & 1 & 2 & 3 & 3 & 4 & 4 & 5 & 5 & 6 & 7 & 8 & 0.149 & 0.158 & 0.111 \\
D & 0.33 & 0.5 & 0.5 & 1 & 2 & 2 & 3 & 3 & 4 & 4 & 5 & 6 & 7 & 0.029 & 0.109 & 0.099 \\
E & 0.25 & 0.33 & 0.33 & 0.5 & 1 & 1 & 2 & 2 & 3 & 3 & 4 & 5 & 6 & 0.099 & 0.074 & 0.086 \\
F & 0.25 & 0.33 & 0.33 & 0.5 & 1 & 1 & 2 & 2 & 3 & 3 & 4 & 5 & 6 & 0.099 & 0.074 & 0.086 \\
\hline
\end{tabular}




\section{Continued}

\begin{tabular}{|c|c|c|c|c|c|c|c|c|c|c|c|c|c|c|c|c|}
\hline & 0.2 & .25 & 0.25 & 0.33 & 0.5 & 0.5 & 1 & 1 & 2 & 2 & 3 & 4 & 5 & 0.065 & 0.048 & 0.07 \\
\hline & ? & & & & & & & & 2 & & & 4 & 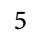 & & 0.048 & 0.07 \\
\hline & 017 & 0.2 & 0.2 & 0.25 & & & & & & & & & 4 & & & \\
\hline & 0.17 & 0.2 & 0.2 & 0.25 & & & & & & & & & 4 & & & \\
\hline & & & & 0.2 & & 0.25 & & & & & & & 3 & & & 0.0 \\
\hline & 0.13 & 14 & 14 & & 0.2 & & 0.25 & 0.25 & 0.33 & 0.3 & 0.5 & & 2 & 0.021 & 0.016 & 0.03 \\
\hline & & $.1 J$ & $.1 J$ & & & 0.17 & & & 0.25 & 0.25 & 0.33 & 0.5 & & 0.012 & 0.012 & 0.0 \\
\hline
\end{tabular}

Pairwise comparison matrix (A): Urban area; (B): Villages; (C): Rivers; (D): Groundwater depth; (E): Slope; (F): Elevation; (G): Soil types; (H): Geological formations; (I): Roads; (J): Oil and gas field; (K): Land use classification (L): Archaeological site; (M): Power lines. NW = Normalized weight.
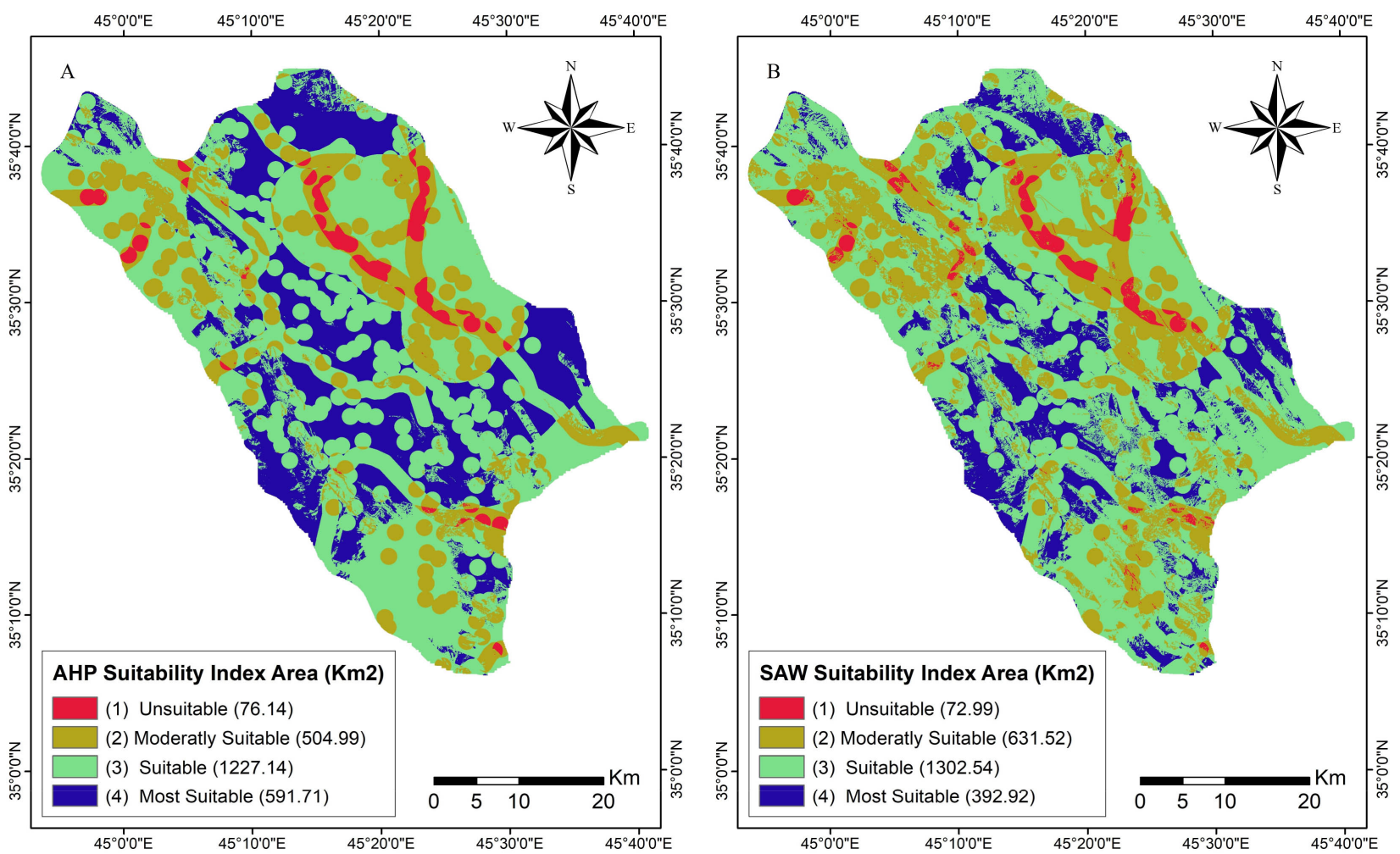

Figure 5. Suitability index area for landfill site using SAW and AHP methods.

\section{Conclusion}

This research used the MCDM techniques with the GIS method to evaluate the suitable selection of landfill sites in the study region. The result shows the index values that have been categorized into 4 areas with calculated area using the pixel calculation in GIS. The results indicate that the most suitable area covered the area of $16.37 \%$ and $24.35 \%$ or 392.92 and $591.71 \mathrm{~km}^{2}$ respectively in SAW and AHP methods, the compatibility of the most suitable area in both methods is 91.71 percent, while the compatibility of all zone areas in both methods is 99.8 , 94.7 and 96.85 percent, respectively, for unsuitable, moderately suitable and suitable respectively. 


\section{Conflicts of Interest}

The authors declare no conflicts of interest regarding the publication of this paper.

\section{References}

[1] Minghua, Z., et al. (2009) Municipal Solid Waste Management in Pudong New Area, China. Waste Management, 29, 1227-1233. https://doi.org/10.1016/j.wasman.2008.07.016

[2] Moeinaddini, M., Khorasani, N., Danehkar, A., Darvishsefat, A.A. and Zienalyan, M. (2010) Siting MSW Landfill Using Weighted Linear Combination and Analytical Hierarchy Process (AHP) Methodology in GIS Environment (Case Study: Karaj). Waste Management, 30, 912-920. https://doi.org/10.1016/j.wasman.2010.01.015

[3] Othman, N. (2017) Environmental Health Assessment in Sulaymaniyah City and Vicinity.

https://www.researchgate.net/publication/317064521_Environmental_Health_Asses sment_in_Sulaymaniyah_City_and_Vicinity

[4] Ugwuanyi, R. and ChimaIsife, T. (2012) Urbanization and Solid Waste Management Challenges in Nigeria. Environment Project.

https://www.researchgate.net/publication/319448696

[5] Chabuk, A., Al-Ansari, N., Hussain, H.M., Knutsson, S., Pusch, R. and Laue, J. (2017) Combining GIS Applications and Method of Multi-Criteria Decision-Making (AHP) for Landfill Siting in Al-Hashimiyah Qadhaa, Babylon, Iraq. Sustain, 9, 1932. https://doi.org/10.3390/su9111932

[6] Li, Z.W., Zeng, G.M., Zhang, H., Yang, B. and Jiao, S. (2007) The Integrated Eco-Environment Assessment of the Red Soil Hilly Region Based on GIS: A Case Study in Changsha City, China. Ecological Modelling, 202, 540-546. https://doi.org/10.1016/j.ecolmodel.2006.11.014

[7] Thapa, R.B. and Murayama, Y. (2008) Land Evaluation for Peri-Urban Agriculture Using Analytical Hierarchical Process and Geographic Information System Techniques: A Case Study of Hanoi. Land Use Policy, 25, 225-239. https://doi.org/10.1016/j.landusepol.2007.06.004

[8] Abdullah, T.O., Ali, S.S., Al-Ansari, N.A. and Knutsson, S. (2018) Possibility of Groundwater Pollution in Halabja Saidsadiq Hydrogeological Basin, Iraq Using Modified DRASTIC Model Based on AHP and Tritium Isotopes. Geoscience, 8, 236. https://doi.org/10.3390/geosciences8070236

[9] Sener, B., Süzen, M.L. and Doyuran, V. (2006) Landfill Site Selection by Using Geographic Information Systems. Environmental Geology, 49, 376-388.

http://onlinelibrary.wiley.com/doi/10.1002/cbdv.200490137/abstract https://doi.org/10.1007/s00254-005-0075-2

[10] Teknomo, K. (2006) Analytic Hierarchy Process (AHP). Measuring Business Excellence.

[11] Şener, Ş., Sener, E. and Karagüzel, R. (2011) Solid Waste Disposal Site Selection with GIS and AHP Methodology: A Case Study in Senirkent-Uluborlu (Isparta) Basin, Turkey. Environmental Monitoring and Assessment, 173, 533-554.

https://doi.org/10.1007/s10661-010-1403-x

[12] Uyan, M. (2014) MSW Landfill Site Selection by Combining AHP with GIS for Konya, Turkey. Environmental Earth Sciences, 71, 1629-1639.

https://doi.org/10.1007/s12665-013-2567-9 
[13] Abdullah, L. and Adawiyah, C.W. (2014) Simple Additive Weighting Methods of Multi Criteria Decision Making and Applications: A Decade Review. International Journal of Information Processing and Management, 5, 39-49. https://pdfs.semanticscholar.org/05a0/d6d88b7a86fd783f736532af68e0e297e299.pdf

[14] Effat, H.A. and Hegazy, M.N. (2012) Mapping Potential Landfill Sites for North Sinai Cities Using Spatial Multicriteria Evaluation. The Egyptian Journal of Remote Sensing and Space Sciences, 15, 125-133. https://doi.org/10.1016/j.ejrs.2012.09.002

[15] Korucu, M.K. and Karademir, A. (2014) Siting a Municipal Solid Waste Disposal Facility, Part II: The Effects of External Criteria on the Final Decision. Journal of the Air \& Waste Management Association, 64, 131-140. https://doi.org/10.1080/10962247.2013.809388

[16] KSRO (2012) Population Estimates for the Kurdistan Region by Governorate and District 2009-2015. http://www.krso.net/files/articles/300616041322.pdf

[17] Office of UN Resident Co-Ordinator (2002) Common Country Assessment. 92. http://www.sprep.org/att/IRC/eCOPIES/Countries/Vanuatu/3.pdf

[18] Simpson, A. and Dandy, G. (1996) Expert System for Water Treatment Plant Operations. Journal of Environmental Engineering, 122, 515-523.

[19] Kara, C. and Doratli, N. (2012) Application of GIS/AHP in Siting Sanitary Landfill: A Case Study in Northern Cyprus. Waste Management \& Research, 30, 966-980. https://doi.org/10.1177/0734242X12453975

[20] Sharifi, M., et al. (2009) Integrating Multi-Criteria Decision Analysis for a GIS-Based Hazardous Waste Landfill Sitting in Kurdistan Province, Western Iran. Waste Management, 29, 2740-2758. https://doi.org/10.1016/j.wasman.2009.04.010

[21] Han, D. and Currell, M.J. (2017) Persistent Organic Pollutants in China's Surface Water Systems. Science of the Total Environment, 580, 602-625.

https://doi.org/10.1016/j.scitotenv.2016.12.007

[22] Bin Chang, N., Parvathinathan, G. and Breeden, J.B. (2008) Combining GIS with Fuzzy Multicriteria Decision-Making for Landfill Siting in a Fast-Growing Urban Region. Journal of Environmental Management, 87, 139-153. https://doi.org/10.1016/j.jenvman.2007.01.011

[23] Hung-Yueh, L. and Kao, J.J. (1999) Enhanced Spatial Model for Landfill Siting Analysis. Journal of Environmental Engineering, 125, 845-851. https://doi.org/10.1061/(ASCE)0733-9372(1999)125:9(845)

[24] Isalou, A.A., Zamani, V., Shahmoradi, B. and Alizadeh, H. (2013) Landfill Site Selection Using Integrated Fuzzy Logic and Analytic Network Process (F-ANP). Environmental Earth Sciences, 68, 1745-1755. https://doi.org/10.1007/s12665-012-1865-y

[25] Yesilnacar, M.I., Süzen, M.L., Kaya, B.Ş. and Doyuran, V. (2012) Municipal Solid Waste Landfill Site Selection for the City of Şanliurfa-Turkey: An Example Using MCDA Integrated with GIS. International Journal of Digital Earth, 5, 147-164. https://doi.org/10.1080/17538947.2011.583993

[26] Nas, B., Cay, T., Iscan, F. and Berktay, A. (2010) Selection of MSW Landfill Site for Konya, Turkey Using GIS and Multi-Criteria Evaluation. Environmental Monitoring and Assessment, 160, 491-500. https://doi.org/10.1007/s10661-008-0713-8

[27] Demesouka, O.E., Vavatsikos, A.P. and Anagnostopoulos, K.P. (2014) GIS-Based Multicriteria Municipal Solid Waste Landfill Suitability Analysis: A Review of the Methodologies Performed and Criteria Implemented. Waste Management \& Research, 32, 270-296. https://doi.org/10.1177/0734242X14526632 
[28] Buringh, P.D. (1960) Soils and Soil Conditions in Iraq. Ministry of Agriculture, Baghdad, 13-72.

[29] Yildirim, V. (2012) Application of Raster-Based GIS Techniques in the Siting of Landfills in Trabzon Province, Turkey: A Case Study. Waste Management \& Research, 30, 949-960. https://doi.org/10.1177/0734242X12445656

[30] Baiocchi, V., Lelo, K., Polettini, A. and Pomi, R. (2014) Land Suitability for Waste Disposal in Metropolitan Areas. Waste Management \& Research, 32, 707-716. https://doi.org/10.1177/0734242X14545642

[31] Ersoy, H. and Bulut, F. (2009) Spatial and Multi-Criteria Decision Analysis-Based Methodology for Landfill Site Selection in Growing Urban Regions. Waste Management \& Research, 27, 489-500. https://doi.org/10.1177/0734242X08098430

[32] Gupta, R., Kewalramani, M.A. and Ralegaonkar, R.V. (2003) Environmental Impact Analysis Using Fuzzy Relation for Landfill Siting. Journal of Urban Planning and Development, 129, 121-139. https://doi.org/10.1061/(ASCE)0733-9488(2003)129:3(121)

[33] Chabuk, A.J., Al-Ansari, N., Hussain, H.M., Knutsson, S. and Pusch, R. (2017) Landfill Sites Selection Using Analytical Hierarchy Process and Ratio Scale Weighting: Case Study of Al-Mahawil, Babylon, Iraq. Engineering, 9, 123-141. https://doi.org/10.4236/eng.2017.92006

[34] Jassim, S.Z. and Goff, J.C. (2006) Geology of Iraq.

[35] Aksaker, N., et al. (2015) Astronomical Site Selection for Turkey Using GIS Techniques. Experimental Astronomy, 39, 547-566. https://doi.org/10.1007/s10686-015-9458-x

[36] Chang, C.W., Wu, C.R., Lin, C.T. and Lin, H.L. (2007) Evaluating Digital Video Recorder Systems Using Analytic Hierarchy and Analytic Network Processes. Information Sciences, 177, 3383-3396. https://doi.org/10.1016/j.ins.2007.02.010

[37] Pecchia, L., Bath, P.A., Pendleton, N. and Bracale, M. (2011) Analytic Hierarchy Process (AHP) for Examining Healthcare Professionals' Assessments of Risk Factors: The Relative Importance of Risk Factors for Falls in Community-Dwelling Older People. Methods of Information in Medicine, 50, 435-444. https://doi.org/10.3414/ME10-01-0028

[38] Saaty, T.L. (1980) The Analytic Hierarchy Process: Planning, Priority Setting, Resource Allocation. McGraw-Hill, New York. https://doi.org/10.21236/ADA214804

[39] Arisman (2014) Nitric Oxide Chemistry and Velocity Slip Effects in Hypersonic Boundary Layers. 43rd Fluid Dynamics Conference, San Diego, 24-27 June 2013, No. 1. https://doi.org/10.2514/6.2013-3104

[40] Saaty, T.L. and Kearns, K.P. (1985) The Analytic Hierarchy Process. In: Saaty, T.L. and Kearns, K.P., Eds., Analytical Planning, Elsevier, Amsterdam, 19-62. https://doi.org/10.1016/B978-0-08-032599-6.50008-8

[41] Sólnes, J. (2003) Environmental Quality Indexing of Large Industrial Development Alternatives Using AHP. Environmental Impact Assessment Review, 23, 283-303. https://doi.org/10.1016/S0195-9255(03)00004-0 